folk/ed. Derg, 2021; 27(3)-107. say1

DOI: $10.22559 /$ folklor.1699

Derleme makalesi/Compilation article

\title{
Türk ve Batı Edebiyatında Çingene İnançları
}

\author{
Gypsy Beliefs in Turkish and Western Literature
}

Alparslan Oymak

$\ddot{O} z$

Çingeneler yüzyıllar boyunca hem gerçek yaşamda hem de edebî eserlerde önyargılı yaklaşımların hedefi olmuşlardır. Bunların başında dinsiz olup hiçbir şeye inanmaları gelir. Türk ve Batı edebiyatında Çingenelerle ilgili olumsuz görüşlerin yayılmasında haklarında türetilen efsane ve hikâyelerin payı ilk sıralarda yer alır. Çingenelerin kötü şöhretlerinin yayılmasındaki diğer bir neden de yaşam tarzlarının toplumun genel yapısına uygun görülmemesidir. Şehir sistemine uymadıkları için yabani oldukları, daha doğrusu medeniyetin karşısında bir tehdit oldukları algısı yaygındır. Göçebe olsun ya da olmasın, dışarıya kapalı gruplar şeklinde yaşayan Çingeneler, toplumun geneli tarafından ötekileştirilmiş ve bu durum da eserlere aynı doğrultuda yansımıştır. Türk ve Batı edebiyatında ahlak, inanç, temizlik, hırsızlık gibi konularda önyargılarla betimlenmelerine rağmen Çingenelere daha içeriden bakan azımsanmayacak sayıda eser mevcuttur. Tüm bu eserler incelendiğinde yaygın görüşün aksine Çingenelerin katı kuralları olan bir inanç sistemine ve köklü bir geleneğe sahip oldukları anlaşılmaktadır.

Geliş tarihi (Received):27.03.2021 - Kabul tarihi (Accepted): 11.07.2021

* Arş. Gör. Dr. Yıldız Teknik Üniversitesi Fen-Edebiyat Fakültesi Türk Dili ve Edebiyatı Bölümü.(Yı1dız Technical University, Faculty of Arts and Sciences, Department of Turkish Language and Literature). alpoymak@hotmail.com. ORCID 0000-0003-1759-7336 
Temizlikle ilgili marhime inançları, kadın erkek ilişkileri ve cinsellikle ilgili tabuları onlarla ilgili olumsuz görüşlerin tam aksini işaret eder. Çingeneleri konu edinen eserlerde, hayata bakışları, zaman algıları, ölüm karşısındaki tavırları, aileye verdikleri önem ve dili kullanım biçimleri toplu olarak değerlendirildiğinde Çingenelerin inanç sistemleri daha anlaşılır hâle gelmektedir.

Anahtar sözcükler: Çingeneler, Çingene inançları, Türk edebiyatı, Batı edebiyatı, ötekileştirme

\begin{abstract}
Gypsies have been the target of prejudiced approaches in real life and literary works for centuries. The most important of these is their being irreligious and believing in nothing. In the spread of negative opinions about Gypsies in Turkish and Western literature, the share of legends and stories derived from them is at the top. Another reason for the spreading of the bad reputation of Gypsies is that their lifestyle is not seen as suitable for the general structure of the society. There is a widespread perception that they are wild, or rather a threat to civilization, because they do not fit into the city system. Whether they are nomadic or not, Gypsies living in closed groups have been marginalized by the general public and this situation is reflected in the works in the same direction. Although they are depicted with prejudices on issues such as morality, belief, cleanliness and theft in Turkish and Western literature, there are a considerable number of works that look at Gypsies from within. When all these works are examined, it is understood that Gypsies have a belief system with strict rules and a deep-rooted tradition, contrary to the common opinion. Marhime beliefs about cleanliness, male and female relationships and taboos about sexuality point to the exact opposite of negative views about them. The belief systems of Gypsies become more comprehensible when their view of life, their perception of time, their attitudes towards death, the importance they give to the family and their use of language are collectively evaluated in the works dealing with Gypsies.
\end{abstract}

Keywords: Gypsies, Gypsy beliefs, Turkish literature, western literature, marginalisation

\title{
Giriş
}

Bu makalede Türk ve Batı edebiyatında Çingene olarak adlandırılan toplulukların ortak kültürel yaşantılarının eserlere yansımaları, hiçbir şeye inanmadıkları düşünülen Çingenelerin inançları ve "gaco"larla yani Çingene olmayanlarla Çingenelerin birbirlerini nasıl gördükleri ele alınmıştır. ${ }^{1}$ Makalenin cevap aradığı temel sorulardan biri Çingenelerin neden önyargılı suçlamalara maruz kaldıkları ve sanki ortak bir kararla nasıl ötekileştirildikleridir. Çingeneleri ele alan eserler edebiyat sosyolojisi bağlamında ele alınarak bakış açısı temelli bir yaklaşım ortaya konmuştur. Bununla, yazarın ve toplumun Çingenelere nasıl yaklaştıkları ve önyargılı 
tutumları saptanmıştır. Elde edilen tüm veriler incelendiğinde Çingenelerin dışlanmalarındaki en önemli etkenin toplumsal düzene karşı bir tehdit olarak algılanmalarından kaynaklandığı tespit edilmiştir. Ayrıca insan doğasının ehlileştirilmesi sürecinin ya da medeniyet kavramına yüklenen anlamların da var olan önyargılara temel teşkil ettiği görülmektedir.

Dünyanın dört bir yanına yayılmış, farklı klanlardan oluşan Çingene toplulukları, kendilerine has inanç, kültürve geleneklerini koşulların el verdiğiölçüdekoruyupyaşamışlardır. Hindistan'dan çıktıkları uzun yolculuk boyunca belli bir asimilasyona uğramış olsalar da Çingenelerin temel değerlerini koruma konusunda kararlı oldukları söylenebilir. Yalnız bu noktada konargöçerlerin daha tutucu oldukları belirtilmelidir. Üzerinde çalışılan edebî eserlerde de yerleşiklerle göçerler arasındaki ikilik açıkça görülmektedir. Şöyle ki; göçerler, yerleşik Çingeneleri köklerinden kopmuş ve gacolaşmış olarak görürler. Geleneklerinden uzaklaştığı düşünülen kişi ise kendi çevresi tarafından artık bir ölü hükmündedir (McCann, 2007: 25). Yerleşik olanları ise diğerlerini kendilerinden daha aşağı seviyede görürler. Burada sorulması gereken sorulardan biri, yerleşik Çingenelerin geleneklerinden gerçekten uzaklaşıp uzaklaşmadıkları, ikincisi ise göçebe Çingenelerin kendi inançlarını ne kadar yaşayıp yaşamadıklarıdır.

Kuşkusuz dünyada asılsız biçimde en fazla suçlamaya maruz kalan topluluklardan biri Çingenelerdir. Onlarla ilgili suçlamalar ya da önyargılar belli başlıklar altında toplanıp değerlendirildiğinde hem Çingene gelenekleri hem de Çingene olmayanların onlarla ilgili düşünceleri daha açık biçimde anlaşılabilir. Bu başlıklardan ilki Çingenelerle ilgili yaratılmış olan efsanelerdir.

\section{1. Çingenelerle ilgili efsaneler}

Çingenelerle ilgili efsaneler aynı zamanda bu toplumla ilgili yıkılması çok zor önyargıları da beraberinde getirmişlerdir. Çingeneler bugün hâlâ eski hikâyelerin adeta lanetiyle yaşamaya devam etmektedirler. İncil'e dayandırılan anlatılar ise özellikle dikkat çekicidir.

İncil'e göre Kabil, kardeşi Habil'i öldürünce dünyayı dolaşmakla lanetlenir. Buna göre toprağı işlediklerinde ürün alamayacaklar ve dünyada bir kaçak gibi dolaşıp duracaklardır (Fonseca, 2002: 103). Bu alıntının önemi, Çingenelerin, Kabil'in dünyada başıboş gezmekle lanetlenen torunları olduğu inancının yaygın olmasındandır. Böylelikle Çingenelerin toprakla uğraşmamalarının sözde nedeni de gösterilmiş olur. Kabil adının Çingenelerde yaygın bir meslek olan nalbant anlamına gelmesi ise ilginçtir. Tabii bu söylencenin Çingenelerde yaygın olan metal işçiliğinden yola çıkılarak kurgulanmış olması da muhtemeldir.

Çingenelerin kendileri tarafından anlatılan hikâyeler de İncil'dekilerle örtüşür. Mısır'dan çıkarken Yusuf ve Meryem'e yardım etmedikleri, Yahuda'ya, İsa'ya ihanet etmesini söyledikleri, İsa'nın çarmıha gerilmesinde kullanılan çivileri yaptıkları için sürekli dolaşmaya mahkûm oldukları bunlardan en bilinenleridir. İşledikleri suçlara bakıldığında Hristiyanların gözünde en büyük günahları işledikleri açıktır. Gerçi Mısır kökenli oldukları söylentisi, bir yurtları olduğunu gösterdiği ve önceleri işlerine yaradığını düşündükleri için Çingeneler tarafından özellikle yayılmıştır (Fonseca, 2002: 104). 
Yine din konusu üzerinden gidildiğinde, Bulgaristan'da anlatılan küçümseyici bir hikâyede, Tanrı'nın insanlara dinleri dağıtırken Çingenelerin dinlerini lahana yapraklarına yazdıkları belirtilir. Ancak bu yapraklar bir eşeğin yemeği olunca da dinsiz kalırlar. Romanya'da anlatılan benzer bir hikâyeye göre de Çingeneler kiliselerini taştan, Rumenler ise domuz pastırması ve jambondan yaparlar. Bir gün karşılıklı olarak kiliseleri değişmeyi kabul ettikten sonra Çingeneler hemen pastırma ve jambondan oluşan kiliseyi yerler. Surbistan'daki anlatıma göre dilenmelerinin nedeni kilise meselesi ile ilgili olarak sadece haklarını istemelerinden ibarettir (Fonseca, 2002: 103).

Çingenelerin bir yere ait olmayışlarıyla ilgili bir hikâyeye göre de 5. yüzyılda İran Şahı Bahram Gur, Hindistan'dan yirmi bin müzisyen getirtir. Şah, Hindistan'dan getirttiği müzisyenlerin her birine eşek, öküz ve mısır verir. Amacı onları tarıma yapmaya sevk etmektir. Ancak Çingeneler tüm mısırı ve öküzleri yedikten sonra perişan şekilde geri dönerler. Bu yüzden tüm lavtacılar artık dışarıda uyuyarak, dilenerek ve hırsızlık yaparak yaşamaktadırlar (Fonseca, 2002: 108).

Çingenelerin lanetlenmeleriyle ilgili bu yaygın hikâye, Ağlayan Dă̆ Susan Nehir'de de aynı yerde bir daha gecelememeleri ve aynı kaynaktan ikinci kez su içmemeleri biçiminde yer bulur (Devecioğlu, 2015: 1). Çingenem Çengi Çengi'deki anlatıya göre de Hz. İbrahim'i ateşe atmayı başaramayan Nemrut'a Şeytan yardım eder. Bunu başarabilmek için biri kız diğeri erkek iki kardeşin birlikte olmaları gerektiğini söyler. Efsaneye göre Çingene sözcüğü Cin ile Kan adlı bu iki kardeşten gelmektedir (Kılıç, 1986: 107).

Bu biçim karalayıcı efsanelerin sonucu olan, örneğin Avrupa'da, ceset yedikleri ya da yamyam olduklarıyla ilgili yayınların etkilerini yitirmeleri için yüz yıldan fazla bir sürenin geçmesi gerekmiştir. 1782'de Macaristan'da yamyamlık suçlamasıyla tutuklanan yüz elli Çingene'den kırk birine işkenceyle yamyam oldukları itiraf ettirilmiştir. Böyle bir şeyin olmadığı anlaşılana kadar birçoğu öldürülmüştür. 1929 gibi yakın bir tarihte bile Slovakya' da bir Roman soygun çetesinin kurbanlarını yedikleriyle ilgili dava gazetelerde haftalarca yer almıştır (Fonseca, 2002: 103-104).

Yukarıda bahsedilen olayların benzerleri Avrupa'nın çeşitli ülkelerinde işkenceden idama kadar giden bir seyir izlemiştir. Tüm bu karalama kampanyalarının vardığı son nokta ise II. Dünya Savaşı'nda Naziler tarafından toplama kamplarına konulan yüzbinlerce Çingenenin hayatını kaybetmesidir. Arkalarında herhangi bir lobileri olmadığı için hiçbir zaman haklarını aramaları mümkün olmamış, uluslararası kamuoyu tarafından görmezden gelinmişlerdir.

\section{Din/İnanç}

\subsection{Din}

Ahmet Midhat Efendi, Çingenelerin dini inançlarının gizli olduğunu ve bunu kimseye açıklamadıklarını belirtirken pek de haksız değildir (Midhat, 2001). Yazılı kaynaklarının olmayışı ve içe dönüklükleri bunda etkilidir ki konumları gereği bu gayet anlaşılır bir durumdur. Bununla beraber Çingenelerin inançlarıyla ilgili yaygın kanı ya dinsiz oldukları 
ya da gittikleri yerdeki ortama uyum sağladıklarıdır. Üçüncü bir görüşse aslında kendi inançlarından hiç vaz geçmedikleri, baskılardan kurtulmak için din değiştirmiş gibi görünmeleridir. Macaristan ve Romanya'da anlatılan, Çingenelerin domuz yağından yapılmış kiliselerinin köpekler tarafindan yendiğiyle ilgi fikra aslında onların herhangi bir şeye inanamadıklarıyla ilgili önyargının ürünüdür (Berger, 2015: 11).

Zaharia Stancu da bu düşünceyle doğru orantılı olarak, Çingenem'de, Çingenelerin inançsız olduklarını da sık sık vurgular. (Stancu, 1971: 10). Prosper Mérimée ise ünlü eseri Carmen'de Stancu'nun tersine, Çingenelerin hiçbir zaman dinsizliğe sürüklenmediklerini, göç ettikleri yerin dinini aldıklarını belirtir. (Mérimée, 2011: 13). Ancak Mérimée'nin aksine aynı konuyla ilgili başka bir değerlendirme de Evliya Çelebi'de görülür:

"Rumeli Kıptileri kâfir ile Kızılyumurta bednâm günlerin edüp Müselmanlar ile 1yd-1 adhâ edüb Yahudiler ile kamış bayramların edüp bir mezheb kabul etmedikleri ecilden cenazelerinin namazların e'immelerimiz kılmayup eğrikapu haricinde Çinganeler içün başka bir gûristan yeri verdiler" (Çelebi, 2011: 37).

$\mathrm{Bu}$ alıntıdan da anlaşılabileceği gibi Çingeneler yaşadıkları yerlerdeki her dinin bayramını kutlamışlar, bunun yanında mezhepsiz oldukları için cenaze namazları imamlar tarafından kılınmamış ya da kendileri kıldırmamışlardır. Sonuç olarak Çingenelerin tepki çekmemek için yaşadıkları yerlerdeki dine ayak uydurdukları anlaşılmaktadır.

Çingenelerle ilgili bu toptancı yaklaşım zaman zaman onları bu görüşün aksini ispat etme çabasına itmiştir. Otobiyografik bir eser olan Bir Çingenenin Romanı'nda, Mestan Usta, hangi dine mensup olduklarının sorulmasından rahatsız olur ve Müslüman olduklarının altını çizer (Dinçer, 2014: 43). Bu durum zaman zaman Çingeneliği reddetme aşamasına da geçmiştir. Çingeneler Başka Dünyanın İnsanları'ndaki bir çiçekçi, verdikleri röportaj sonrası gazetede kendileri için Çingene tabirinin kullanılmasına içerlemiştir (Alpman, 2014: 68). İçerlemesinin nedeni Çingeneden önce Müslüman olarak görülmek istemesidir. Benzer şekilde Kâğıthaneli Ayıcı Alaattin de Sulukulelilerin Roman olduğunu, Müslüman olmadıklarını belirtir. Yani hem Roman hem Müslüman olmaları mümkün görülmez (Alpman, 2014: 72). Ümraniye'deki davulcular da artık İslamiyet'e yaklaştıkları için Çingeneliği reddederler ve Hıdırellez'i de kutlamadıklarını da eklerler (Alpman, 2014: 89).

Yukarıdaki alıntılar Müslümanlığın, Çingeneliği örten bir üst kimlik olarak kullanıldığını göstermesi bakımından önemlidir. Kuşkusuz bu çabanın altında toplum içinde var olabilme mücadelesi yatar.

Genel olarak inanç düzlemine geçildiğinde ise Çingenelerin anlatıldığı eserlerin çoğunda Allah'a ve Şeytan'a inanmalarına rağmen onları sürekli dile getirmedikleri görülür.

Osman Cemal Kaygılı'nın Çingeneler'inde Allah'a Odel, Şeytan'a da Beng denildiği, cin ve peri için de bengal kelimesinin kullanıldığı aktarılır (Kaygıll, 1972: 41). Romanda kurnaz ve gizemli olarak çizilen Ethem'in namaz kılma biçimi Çingenelerin dindar gibi göründükleri önyargısını destekler niteliktedir. Sözde namaz kılar gibi yapan Ethem dua yerine de Çingenece tekerlemeler okur (Kaygıl1, 1972: 251). Ayrıca ettiği duaları So'ya gönderdiğini söyler. So da büyük efendi, büyük mal sahibi yani Allah anlamına gelir. Burada 
namaz ve dua sahnesiyle mizah unsurunun oluşturulmasının yanında Ethem'in gacoları bir anlamda alaya aldığı da görülmektedir.

Bunun dışında Tanrı kavramının efsaneleşmiş bir versiyonuna, Vidoe Podgoreç'in Çingeneler Arasında adlı eserinde rastlanır. Romanda bütün Çingenelerin tanrısının "Penga" olduğu söylenir. Masala göre göğün yedinci katında yaşayan Penga'nın iki beyaz atın çektiği altından bir arabası vardır. Bir gün arabasının tekerleği çıkınca yeryüzüne düşer. Çok uzun süre yardım bekledikleri için de çocukların yüzleri güneşten kararır. Dünyada kalan Çingeneler köylülerin buğdaylarını ezdikleri için oradan kovulurlar. Kalkıp sarayını aramaya koyulan Penga ise geri dönüş yolunu bir türlü bulamaz. Geri dönme ihtimali kalmayınca da herkese bir meslek edinmesini söyler. Böylelikle Çingeneler demirci, çalgıcı, ayıcı, dilenci vb. olarak hayatlarına devam ederler (Podgoreç, 1978: 45).

Görüldüğü gibi at, araba ve zor günlerin kurtarıcısı olarak değer gören altın, tıpkı Çingenelerin doğal hayatlarında yer edindikleri gibi efsaneye de yansımışlardır. Efsaneye Çingenelerin çalışmayı sevmedikleri ve gamsız oldukları kanısı hâkimdir. Bu olumsuz özellikleri bir anlamda esmer olmalarının da nedeni olarak verilmiştir. İlginç olan, Çingenelerin kendi efsanelerinde gacoların önyargılarıyla aynı düzlemde bir değerlendirmeye gitmeleridir.

Çingenelerin kökeni ile bağlantılı asıl yaygın efsane ise farklı çeşitlemeleri olan Firavun efsanesidir. Anlatı, Çingenelerin kökenlerini Hz. Musa'nın Kızıl Deniz'i asasıyla yardıktan sonra hayatta kalan Mısırlılara dayandırmalarına da kaynaklık eder. Çingenelerin büyük atalarından biri sayılan ve bir aziz konumunda tasvir edilen Pharavono, Kutsal Topraklar'ı ellerinden almak için Türk Yahudileri ve Hıristiyanları ile savaşırlar. Ancak düşmanlarının komutanı Sinpetra'nın Tanrı'nın kendisi olduğundan habersizdir. Tuz Denizi'ni geçmek için Tanrı'ya dua ettiğinde deniz ikiye ayrılır ancak Pharavono ve ordusu tam ortaya geldiklerinde geçit kapanır. İşte buradan kurtulan birkaç Pharavunure, Zagrebo'ya ulaşır ve buradan dünyaya yayılırlar (Berger, 2015: 47-48). Bu efsanenin yayılmasında firavun isminin Çingenecede "ayırmak" anlamına gelen phar-, pharav- sözcüğüyle kazandığı çağrışım da etkili olmuştur (Berger, 2015: 50). Çingenelerin Yahudilerle olan çekişmelerine bir neden olarak Babafingo efsanesinden de bahsetmek gerekir. Buna göre kral Babafingo, zamanı geldiğinde bir Çingene devleti kurmak için yeryüzüne çıkacaktır. Sorun şu ki, yeryüzüne çıkış zamanını yalnızca Yahudiler bilmektedir. Bir Çingene ile karşılaşınca onlar için çok önemli olan bu bilgiyi vermemek için arkalarını dönmeleri bu nedenledir. Bu tavra karşı Çingeneler de intikam almak için Yahudiler ibadet ederlerken çalıp oynayarak onları rahatsız etmeye çalışırlar (Önder, 1975: 22-26).

Paulo Coelho'nun Portobello Cadısı'ında ise, Tanrı kavramı dışında, Hristiyanlıkla da bağlantılı olarak Çingenelerin koruyucusu Azize Sara'dan bahsedilir (Coelho, 2008: 117). Çingenelerin Kâbe'si ise tüm kutlamaların yapıldığı Sainyes-Maries-de-la-Mer olarak gösterilir. Efsaneye göre Sara Hz. İsa'nın teyzesi Meryem Salome, Romalılardan kaçıp buraya gelince onlara yardım eder. Ancak daha sonra Hıristiyan da olsa Vatikan tarafindan azize olarak kabul edilmez. Bahsedilen kutlamalar sırasında güzel elbiseler giydirilen heykel sokaklarda dolaştırılıp deniz kıyısına götürülür. Dört çingene, kutsal kalıntıları çiçeklerle süsleyip onu bir tekneye koyup denize salarlar (Coelho, 2008: 138-140). 
Türkiye'deki Çingeneler ise Sulukule'deki Ethem Baba ve Lonca'daki Hoca Ali’yi evliya olarak görmüşlerdir. Bu türbeleri ziyaretleri sırasındaki ritüelleri ise huzurlarında göbek atmaktır (Alpman, 2014: 179). İlginç olan nokta, bu göbek atma ya da Çingenelere has göbek dansı figürlerinin mitolojik bir kökene bağlanmasıdır. Yine Portobello Cadısı'nda geçtiğine göre Ürdün'deki Petra kentinde tüm dünyanın merkezini simgeleyen konik bir göbek vardır. Yunanistan Delphoi'daki Apollon tapınağında da göbek denilen bir mermer bulunmaktadır. Bu ikisi dünyanın enerjisinin geçtiği eksendir ve Hint mitolojisinde yeniden doğumu temsil etmektedir (Coelho, 2008: 167). Bu açıdan bakıldığında Çingenelerdeki göbek dansının temeli dünyayı harekete geçirmek, bir anlamda da yeniden doğumu sağlamak amaçlı Hint inancına dayanır. Hareket vücudun merkezi olarak görülen göbekten başlayıp tüm vücuda yayılır. Göbeğe atfedilen değerin doğum ve göbek bağı ile birlikte, Hint inanışında bir enerji noktası olan karın çakrası ile de çeşitlendirilmesi de mümkündür.

\section{2. Bahar âdetleri}

Hemen her kültürde olduğu gibi Çingeneler için de baharın gelişi yeniden doğumu simgeler ve özel ritüellerle karşılanır. Bu geleneklerden biri Çingenelerin her yıl 5-6 Mayıs'ta Kakava/Hıdırellez bayramı sırasında güneşe dönük vaziyette derede yüzlerini yıkayıp dualar ederek kendi kendilerini kutsamalarıdır (Dinçer, 2014: 235).

Hıdırellez'in bilinen adetlerinden ateşin üzerinden atlama Çingenelerde de benzer şekildedir. Çingene Pilici'nde Celep Osman “destur!” der ve ellerini tükürükleyip alevlerin üzerinden atlar. Ailecek bu hareket on iki defa yeniledikten sonra ateşin etrafına oturulur. Şarap içilirken dua ya da şarkıya benzer bir mırıldanma duyulur. Sonunda Celep Osman ayağa kalkar, ellerini gökyüzüne açarak günahlarının affedilmesi için dua eder (Tokmakçıoğlu, 1975: 55).

Kakava'nın Çingenece tencere bayramı anlamına geldiğinin belirtildiği Romanika Çingenem'de ise gelin ve damat bit ve pirelerin ölmesi için ateşin üstünden atlarlar. Diğer bir gelenek de ormandan topladıkları ağaç dallarının evlerin kapılarına asılmalarıdır. Bunu yapmaktaki amaç şeytanların, cadıların ve kötü ruhlardan korunmaktır. Ayrıca arife günü kuzu eti yenmez çünkü kendi ölmüş çocuklarını yedikleri düşünülür. Evden çıkarılan bir hasırın toplanan başaklarla birlikte yakılması da muhtemelen evin korunması amacıyladır. Başka bir adet de Şeytan Dere'den alınan suya 41 ot ve 41 taş atılması, sabah olunca da bu suyla yıkanılmasıdır (Erdoğdu, 2016: 53).

Yine Hıdırellez'le ilgili ilginç bir adet de "1slak gelin" anlamına gelen Dudulenge eğlenceleridir. Sinan Dede çeşmesinde toplanan kadınlı erkekli çingeneler çimenlerin neminden yaralanarak aşağı doğru yuvarlanırlar (Dinçer, 2014: 302-303).

Baharın gelişi ile ilgili Avrupa kaynaklı tek örnek görülen tek adet Çingene Aşkı'nda görülür. Esere göre Macar Çingeneleri baharın gelişini önce yıkanarak ve en güzel ve temiz kıyafetlerini giyerek kutlamaya başlarlar (Stroheim, 1954: 6).

Verilen örnekler- özellikle Türkiye Çingeneleri ile ilgili olanları - Hint, Pagan ve İslam 
inancının getirdiği ibadetlere ek olarak örneğin cadı inancı da eklenince ilginç bir hâl alır. Ortaya adeta göç coğrafyasının tümünden devşirilmiş bir inanç sitemi çıkmaktadır.

Tanrı, Şeytan, azizlik ya da evliyalık gibi kavramlar dinsel düzlemde en tepede oldukları hâlde, inançlarının gereği olan, özellikle de temizlik/kirlilik (marhime) ve uğur (baht)/ uğursuzluk temelli tabular Çingenelerin yaşamlarını düzenleyen asıl yapı taşları olarak belirginleşirler. Çingeneleri anlatan eserlerde Tanrı korkusu ya da günah kavramından bahsedildiğine rastlanmaz ancak belli âdetler söz konusu olduğunda özellikle de "marhime" inancının getirdiği tabuların günlük hayatta belirleyici rolü olduğu görülür.

\section{3. Temizlik/ Marhime}

Önyargı bağlamında Çingenelerle ilgili en çok dile getirilen konu, temizliğe hiç önem vermedikleridir. Ancak Türk ve dünya edebiyatında Çingeneleri işleyen birçok eser ve araştırmada tam tersi bir durumla karşılaşılır. Daha da ilginç olan nokta Çingenelerin de gacoları pis olarak görmeleridir.

Temizlik konusunda katı kurallara sahip olan Çingeneler pis gördükleri ve uzak durulması gerektiğini düşündükleri şeyleri "marhime” yani kirli olarak tanımlarlar. Kediler, köpekler, fareler, yılanlar, doğum yapmış kadınlar marhimedir. Kediler, tüylerini temizleyerek iç organlarına taşıdıkları, yılanlar da diğer hayvanları kirli derileriyle yedikleri ve deri değiştirdikleri için kirlidirler. (Devecioğlu, 2015: 122) Bu hayvanların tersine, dikenleri sayesinde temiz kalabilen kirpi ise sevilen bir hayvandır ve yenilmesinde bir sakınca görülmemektedir (Fonseca, 2002: 121).

Bahsedilen nedenlerden ötürü Çingeneler, evlerinde kedi köpek besleyen gacoları hayretle karşılarlar. Yılan ve fare söz konusu olduğunda ise Britanya'daki Çingeneler için, bu hayvanların adının anılması bile kirlenmeye neden olabilir. Karanlıkta Ateşler'de Küçük Emil'in kedi besleyip aynı yerde yemek yiyen gacoların olduğundan bahsetmesi dahi kirlenmeye yol açacağı için annesinden bir şamar yemesine neden olur (Doughty, 2005: 115). Yine Çingene Bozena, pis oldukları için küçük kızınının gacoların çocuklarına yaklaşmasını istemez (Doughty, 2005: 45). Bağlı olunan temizlik kurallarına göre kadının teninden mikrop geçebileceği düşünüldüğünden, kadın demliği kocasına uzatırken sapını bir bezle tutarak çaya mikrop bulaştırmaktan kaçınır (Doughty, 2005: 64).

Marhime söz konusu olduğunda su, özellikle de akan su önemlidir. Örneğin Naciye temizlik yapan Sümbül'ü akan su kullanmadığı için Çingenelikle -daha doğrusu Çingene olmamakla- suçlar (Devecioğlu, 2015: 123). Karanlıkta Ateşler'de de bakır küvette kendi kirleri içinde yattıklarından gacolar pis görülürler. Ayrıca bir Çingene kızının kovayı eteklerine değdirmeden taşıması, o kızın bir gelin olarak tercih edilmesi için bile yeterli bir gerekçedir (Doughty, 2005: 192).

Ayrıca bir asker kaçağının çeribaşı Him Başa’nın ayaklarını öpmesi de bir kirlenmedir çünkü adam katildir (Stancu, 1971: 304).

Bu kurallara ek olarak, herkesin kullandığı yemek aletlerinin ağızlarına değmemesine de 
dikkat edilir. Bu nedenle herkes yanında taşıdığı bir bıçağı kullanır. Muhafazakâr Çingene kültüründe sıvılar bir kaptan ağıza akıtılarak kabın dudaklara dokunması engellenir. Eğer birlikte pipo içiliyorsa, pipo etrafına sarılan yumruk yardımıyla içilir. Böylece ağıza temas engellenmiş olur. Bunlara ek olarak yiyecekleri etleri uzun süre yıkamadan da pişirmeye başlamazlar (Fonseca, 2002: 123).

Kuşkusuz Çingenelere karşı toptancı yaklaşım, yukarıdaki temizlik algısının tam olarak zıddını işaret eder. Türk edebiyatında Ahmet Midhat Efendi'den başlamak üzere Çingenelerin pis olduğu, ellerinin değdikleri şeyin murdar olacağı gibi önyargılarla karşılaşılır (Midhat, 2001: 449). Benzer yaklaşımı bir Çingene kadınının saçını bir at yelesiyle kıyaslayan Carmen'de de görmek mümkündür (Mérimée, 2011: 98).

Çingene Aşkı'nda ise tüm bahsedilen katı marhime kurallarının aksine Çingenelerin kedi hatta bir köpek ölüsünü bile yedikleri anlatılır (Stroheim, 1954: 23). Pek de inandırıc1 olmayan bu yaklaşım o dönemdeki yaygın kanının bir ürünü olarak değerlendirebilir. Ancak bu kanının oluşmasında etkili olan bir durum söz konusudur. Slovakya'da en yoksul Çingene mahallelerinde bile evlerin içlerin düzenli olmasına karşın sokaklar her zaman bir çöplük görünümündedir. Nedeni başkasının çöplerine temas etmenin kirlenmeye neden olmasıdır. $\mathrm{Bu}$ da çöpten kapılacak bir hastalıktan daha tehlikelidir. Kirli değillerdir, öyle görünürler (Fonseca, 2002: 45). Bu tercihin nedeni, görünümleriyle gacoları kendilerinden uzak tutmaktır. Çocukların giysilerinin hiç onarılmamalarının nedeni de bu kirli ya da tehlikeli görünümlerini pekiştirmektir (Fonseca, 2002: 62).

Çingenelerin temizliğe verdikleri önem Karanlıkta Ateşler'deki iki sahnede de kendisini gösterir. İlkinde, Çingeneler durakladıkları bir yerde atlarını kulübelere sokup kendileri arabalarda yatarlar. Çünkü insanlar için ayrılan kulübeler onlara göre pistir (Doughty, 2005: 88). Dışarıdan bakıldığında medeniyet dışı gibi görünen bu hareketin tek nedeni ise marhime inancidir.

Çingenelerle geçirdiği günleri kitaplaştıran Jan Yoors, elini yıkamadan yemeğe başladığı için uyarılır çünkü "kirli" hâlde yemek yenmez (Yoors, 2005: 51). Yazar bir ağacın altına işediği için azarlanır. Tuvaletten bahsetmek bile uygun değilken gacoların evlerinin içinde tuvalet bulunmasına şaşırırlar. Onlara göre oraya gidiş amacı bilinen bir insana saygı duyulamaz. Bir kere kullanıldıktan sonra aynı mendili kullanmaları da düşünülemez. Bu yüzden temizlik için sadece akan suyu kullanırlar. Muhtemelen hareket hâlindeki suyun kir tutmayacağını düşünmektedirler. Yine de yıkanmak için başka, mutfak gereçleri ve kıyafetler için nehrin başka bölümleri kullanılır (Yoors, 2005: 63).

Çingenelerde kadının belden aşağısı marhime olarak görülür. Bu yüzden eteğin kendisine ait olmayan bir eşyaya veya bir erkeğe değmemesine dikkat edilir. Eğer etek tabaklara ya da bardaklara dokunursa bir sonraki erkeği kirletmemek için hemen yok edilirler. Yazar anlamadığı ama daha sonra ise takdir ettiği bu kuralların onların rastgele cinsel ilişkiye giren bir toplum olmalarını engellediğini düşünmektedir (Yoors, 2005: 215).

Klandaki bir kadın bir erkeğin önünden ya da iki erkeğin arasından onları kirletme 
potansiyeli olduğu için geçmez. Zorunda kalırlarsa başka bir tarafa dönmesini ister. Aynı şekilde atların da önünden geçmez (Yoors, 2005: 216). Ayrıca yüzünü yıkamamış bir erkekle kimse konuşmaz (Yoors, 2005: 36). Kadın erkek ve çocukların çamaşırlarının da yine ayrı ayrı yıkanmaları gerekir (Yoors, 2005: 48). İç çamaşırları ise diğer çamaşırların altında saklanır ve görülemeyecek bir yere asılır (Fonseca, 2002: 58).

Çingenelerle birlikte yaşayan Fonseca büyük bir cömertlikle karşılandığını ve evin annesi tarafından kızım diye çağrıldığını belirtir. Buna rağmen yemek yapmasına ya da çalışmasına izin verilmez. Hatta kendi kendine bile yıkanması bile mümkün değildir (Fonseca, 2002: 25). Gerçi Fonseca Çingene olmadığı için tedirginlik duymaları normaldir ancak başka bir Çingenelere karşı benzer bir tutum sergilendiği de görülür. Örneğin kurallara uymadıklarını düşündükleri Tşuraraların yemeklerini yemezler. Hatta yaşlılara karşı saygısız tutumları karşısında onların yerine kendileri utanırlar (Yoors, 2005: 236). Bu örnekten de anlaşılabileceği gibi, tabular söz konusu olduğunda Çingeneler arasında da anlaşmazlıkların var olduğu anlaşılmaktadır.

Genel olarak temizlik konusu ele alındığında özellikle akan suya verilen önem, inançları gereği arınmak için Ganj Nehri'ne giren Hintlilerle benzerlik gösterir. Edirne'deki Kakava şenliklerinde de benzer ritüellerin devam ettiğini eklemek gerekir.

\section{Dünya görüşü}

\section{1. Hayat}

Hemen her konuda olumsuz önyargıların kurbanı olan Çingenelerin hayata karşı herhangi bir duruşlarının olduğu da pek düşünülmemiştir. Çingenelerin gerçek anlamda hiçbir şeyi ciddiye almadıkları onlar hakkındaki en yaygın inanışlardandır. Çehov, öyküsündeki yaşlı Çingeneyi tam da bu doğrultuda konuşturur. Ona göre önemli olan gezip görmek ve hayatın tadını çıkarmaktır. Zaten sonrası ölümdür (Çehov, 2004: 206). Burada Çingene klasik söyleme uygun olarak çalışmanın anlamsızlığı ve özgürlük üzerine düşüncelerini söyler. Ancak Çingenelerin hiçbir şeyi dert etmedikleri algısı onların hayatta kalmak için gösterdikleri çabanın her zaman göz ardı edilmesine neden olmuştur.

Dışarıya kapalı bir toplum olmaları dünya görüşleri ile ilgili sınırlı bilgi sunsa da özellikle Çingenelerle yaşamayı tercih etmiş olan yazarların eserleri yol göstericidir. Örneğin Jan Yoors, onlarla yaşadığı dönemde mahremiyetini yaşayabileceği bir kapının özlemini çeker. Bu konuyla ilgili olarak aldığı cevap ise felsefi niteliktedir. Çingeneye göre mahremiyet önce akıldadır. Gacoların başkasının gizlisini saklısını daha iyi araştırmak için kapılara anahtar delikleri yaptığını düşünür. Mahremiyet insanların birbirlerine gösterdiği inceliktir (Yoors, 2005: 71). Bu ifade, neden kendileri ile ilgili konuşmadıklarına ya da gacolara doğruyu söylemediklerine de 1şık tutar.

Kapalı kapılar ardında yaşayamayan yaşlı kadın Lyuba da yaşamak için akan rüzgâra ihtiyacı olduğunu söyler (Yoors, 2005: 115). Akış, yenilenme anlamına da geldiği için akan suya da sadece temizlik için önem vermedikleri anlaşılır. 
Yine Çingenelerle etkileşim içinde büyüyen Patricia Muradi ise Çingenelerin tahmin edilemez insanlar olduğunu deneyimlediğini belirtir. Kimi zaman tamamen vurdumduymaz, kimi zaman da aşırı hassas yani değişkendirler. Ayrıca Çingeneleri anlatan kitaplardan hiçbir şey anlamadığını da ekler. Ona göre Çingeneler ile vals yapamazsınız (Muradi, 2007: 7).

Çingenelerin sorumluluk sahibi olmadığına katılmayan yazar, kendilerine özgü bir anlayış tarzları olduğunu da ekler. Örneğin bir anda şehir değiştirirken hesap kitap yapma gereği de duymazlar. Onlar için eğer yola çıkabiliyorlarsa gerisi önemli değildir (Muradi, 2007: 297).

$\mathrm{Bu}$ örnekler Çingenelerin neden sorumsuzlukla suçlandıklarını da açıklayıcı niteliktedir. Toprağa yerleşme kaygısı taşımamaları bile dışlanmaları için yeterli bir nedendir. Çünkü bu sahip olmak demektir. Herhangi bir şeye sahip olmayı dert etmeyen Çingeneler bu yüzden sistemin dışında kalırlar ve sorumsuzlukla itham edilirler. Bu, gacoların cesaret edebilecekleri bir yaşam tarzı değildir.

Bu konuyla ilgili daha felsefi bir yaklaşım ise Yoors'tan gelir. Onlar için hayat, bir çeşit kendini yeniden tanımlamak anlamına gelen sonsuz bir akıştır. Yazar bu süreçte bıkkınlık gösterilmediğini, zorluklara karşı kişinin istediği tepkiyi göstermekte özgür olduğunu belirtir (Yoors, 2005: 227). Böylelikle Çingenelerin özgürlükten ne anladıkları ortaya çıkmış olur. Hayatın getirdiklerine karşı uygun tepkiyi vermek.

Genel anlamda Çingenelerin hayata karşı bakışlarının aslında hiç de karmaşık olmadığı görülebilir. Yaşlı Bidşika yağmurun oluşturduğu gölcükleri bir bastonla birleştirirken bölen şeyin kötülüğünden bahseder. Hayat bir akışsa ölüm de parçalanmaya yol açan bir bölünme demektir (Yoors, 2005: 231).

Yaz mevsiminin onlar için cennet anlamına gelmesi ve gökyüzünü çatıları gibi görmeleri (Podgoreç, 1978: 110) ya da doğrudan söylenmeyen şeyleri anlamamaları yani mecaza alışık olmamaları (Muradi, 2007: 213) bu basit yaşantılarıyla açıklanabilir.

Tüm bunların dışında Çingenelerin özgür ruhlu oldukları yargısı aslında yine Çingene olmayanlar tarafindan oluşturulmuştur. İlginç olan nokta, bunun hem olumlu hem de olumsuz değerlendirmelerin kaynağı olmasıdır. Bir yandan doğanın özgür çocuğu olarak olumlanan Çingene, bir yandan da yabani denilerek kötülenir. Romantik bir bakış açısıyla aylaklığı övülürken, aynı anda tembellikle suçlandığı da görülür. The Scholar Gypsy'de (Arnold, 2020) bir Çingene grubuna katılan fakir bir Oxford öğrencisinin öyküsü anlatılır. Amacı Çingenelerin sırlarını öğrenerek herkese açıklamak, böylece kendisine yabancılaşan insanlara yol gösterebilmektir. Örnekte görüldüğü gibi modern dünyanın eleştirisi yapılırken Çingenelerin bilgeliklerinden övgüyle söz edilir. Puşkin'in ünlü eseri Çingeneler (Puşkin, 1990) de benzer bir temayı işler. Buradaki Çingeneler de son derece dürüst ve iyi insanlardır. Ancak bu tarz olumlu yaklaşım gösteren eserler sınırlıdır. Önyargılar dönüp dolaşıp onların topluma uyumsuz yabancılar olduğu noktasında birleşir.

\section{2. Ölüm}

Farklı Çingene topluluklarının hayata ve ölüme karşı benzer bir duruş sergiledikleri 
söylenebilir. Ölüm hayatın bir karşılığı olarak görüldüğü için ondan korkulmaz. Çünkü öteki tarafta hiçlik varsa, orada ıstırap da olamaz. Ayrıca eğer yıldızların ötesinde bir yer varsa dünyadakinden daha iyi olması gerektiği kanısındadırlar. Bunun yanında ruhun yeniden doğacağı zaman gelinceye kadar ölümle huzura kavuştuğunu düşünürler (Putnam, 1972: 77). Kendilerine yakıştırdıkları ölüm yine özgürlük anlayışlarıyla doğru orantılıdır. Ölüm döşeğindeki yaşlı bir adamın son arzusu evden dışarıya çıkarılmaktır çünkü gerçek bir Çingene gibi açık alanda ölmek ister (Doughty, 2005: 121). Burada açık alan isteğinin nedeni ruhunun bedenini terk edebilmesidir. Ruhları bile tutsak edeceği düşünülen dört duvar içinde yaşamanın doğalarına ne kadar aykırı olduğunu göstermesi açısından iyi bir örnektir. Öte yandan da ruhun geri gelip bir daha içeri girememesi için ölünün gözlerine ve ağzına taş konulur (Doughty, 2005: 122).

Bir Çingene öldüğü zaman ilk yapılan işlerden bir diğeri de ölen kişiye ait olan tüm eşyaların yakılmasıdır (Fraser, 2005: 209). Ölünün eşyalarının kirlenmeye yol açacağı düşünüldüğü ve bir başkasına verilemeyeceği için en uygun yol budur. Bu yakma işlemiyle ruhun dünya ile bağlantısının koptuğuna inanılır. Hayattayken eşyaya bağlanmayan Çingene öldüğünde bile ondan kurtulmak ister.

Saygıdeğer bir nine öldüğünde kişisel eşyalarıyla birlikte ölenin çadırı da yakılır. Eğer çadır çabucak yanarsa bu hayırlı bir işarettir. Törende, ölenin geride kalanları birleşme gününe kadar rahatça seyredebilmesi için dua edilir ve külleri omuzlardan geriye serpilir (Putnam, 1972: 77). Sonrasında ise geriye kalan madeni parçalar bir çukura atılır. Çabuk paslanmaları için de üzerlerine su dökülüp örtülür. Başka bir gelenek de mezarlara şarap ve brendi dökülmesidir. Bunu çiçek koymaktan daha anlamlı bulurlar.

Çingenelerin ölüme karşı tavırları, hayvanları söz konusu olduğunda da değişmez. Sahip oldukları atlarından biri öldüğünde ondan hiç bahsetmedikleri gibi, bir başkasının da bahsetmesine izin vermezler. Bu değer verilen hayvana son bir sayg1 gösterisi anlamına gelir (Fonseca, 2002: 95).

Tüm bu örneklere bakıldığında ölümden sonra bir hayatın olduğuna inandıkları görülür. İlginç olan nokta, dünyada hiç bitmeyen yolculuklarının öldüklerinde de sürmesidir. Varılacak bir yer var mıdır belirsizdir ama kesin olan devinimin devam ettiği, bu yolculuk sırasında da dünyayı görebildikleridir.

\section{3. Zaman}

Çingenelerin zamana yükledikleri anlam tıpkı hayata bakışlarında olduğu gibi kendilerine özgüdür. Dikkati çeken kısım, akıp giden zamanla ilgili bir kaygıları olmamasıdır. Hatta bu konuda kafa yordukları, geçmişle hesaplaşma ya da gelecekle ilgili sorgulamalarının da olduğu söylenemez. Çingenelerin zaman anlayışları yine Çingene olmayanlar tarafından tanımlanmıştır. Örneğin Yoors, onlarla yaşadığı dönemde zaman kavramını yitirdiğini belirtir. Bunun bir nedeni, günü belli zaman dilimlerine ayırarak yaşamamalarıdır. Kahvaltı ya da akşam yemeğinin ne zaman olacağı da belli değildir. Mevsim bazında ya kış ya da yaz yaşanmaktadır. Bu açıdan bakılınca hangi ayda oldukları da önemli değildir (Yoors, 
2005: 78). Çingenelerin zaman anlayışlarını en iyi açıklayan cümle kuşkusuz "aralıksız bir şimdiki zamanda" yaşadıklarıdır (Yoors, 2005: 69). Benzer bir değerlendirme Stancu'nun Çingenem'inde de görülür. Uzun bir süre onlar için sürekli tekrar eden bir tek an anlamına gelir (Stancu, 1971: 570).

Birebir benzer değerlendirmeleri hem Fonseca'da hem de Devecioğlu'nda görmek ilginçtir. Fonseca kendi gözlemlerine dayanarak Çingeneler için sadece sıcak ve soğuk olarak görülen iki mevsimden bahsederken Devecioğlu, kahramanı Naciye için de aynı durumun söz konusu olduğunu belirtir. Bunların yanında hiçbir gün diğerinden farklı olmadığından hangi günde oldukları da çok önemli değildir. Saat kullanmazlar. Günü alışılmış zaman dilimleri içinde yaşamadıklarından ne zaman yedikleri önemsizdir (Devecioğlu, 2015: 100). Fonseca yaşadıkları zamanı epik bir şimdiki zaman olarak değerlendirirken (Fonseca, 2002: 93), Devecioğlu Çingene mahallesinin, ahalisinin zamansızlığından türediği düşüncesini eserine eklemler. Zamana karşı kayıtsızlıkla ilgili aynı tutum Amerika'daki bir Çingene kralı için de geçerlidir. Öyle ki kendi yaşından bile haberi yoktur, soranlara 45 ile 75 arasında olduğunu söyler (Mitchell, 1972: 17). Kayıt tutma gibi bir gelenekleri olmadığı için gacoların neden her şeyi yazmak zorunda olduklarını da anlamazlar. Doğum tarihlerini bilmemelerinin ya da buna önem vermemelerinin bir nedeni de budur. Hiçbir olayın onları sürekli meşgul etmemesinin nedeni de zaman kavramı ile olan ilişkileriyle hayata bakış açıları birleşince daha anlaşılır hâle gelir (Fonseca, 2002: 73). Çingenelerin zaman karşısındaki kayıtsızlıklarının, birkaç efsane dışında kendi tarihlerine yabancı oluşlarındaki etkenlerden biri olarak ortaya çıktığı görülmektedir. Tarihleri ve ülkeleri olmadığı için üzerinde hak iddia edebilecekleri hiçbir şeyleri de - ki böyle bir talepleri ya da merakları hiç olmamıştır - yoktur.

\section{4. Dil}

Çingenelerin konuştukları dile ve yükledikleri anlamlara ayrı bir önem verdikleri görülür. Sözcük dağarcıkları ise Çingene olmayanların yaygın olarak kullandıkları bazı sözcükleri barındırmamalarıyla onların düşünüş tarzlarını yansıtmaları bakımından aydınlatıcı bilgiler verir. Örneğin Çingene dilinde yazmak ya da okumak anlamında hiçbir sözcük yoktur (Fonseca, 2002: 21). Zamana ya da geçmişe ait duyarlılıkları olmadığı kadar kendi tarihlerini anlatacak bir yazılı kültürleri de yoktur. Yaşam tarzlarının da etkisiyle okula gitme ve okuryazarlık oranın düşük olması yazmak ve okumak ile neden ilgilenmediklerini daha anlaşılır kılmaktadır. Tehlike, sessizlik, kıskançlık (Fonseca, 2002: 67), vazife ve memleket (Stroheim, 1954: 8) için de aynı durum geçerlidir.

$\mathrm{Bu}$ sözcüklerin yokluğu neden korkusuz ya da bir anlamda da sorumsuz olarak görülmelerinin de açıklayıcısı gibidir. Benzer şekilde sessizliğe bir ad vermeye gerek duymayan bir toplumun Çingene olmayanları rahatsız edecek kadar yüksek sesle konuşmaları da anlaşılır bir durumdur. Genel olarak tüm eserlere bakıldığında kıskançlıkla ilgi bir sahneye rastlamak mümkün değildir. Erkeklerin kadınlarını kıskanmamaları hiç kuşkusuz "gaco" bakış açısına göre onların ahlâksızlıkla suçlanmalarına etki etmiştir. Son olarak vazife ve memleket sözcüklerinin yokluğu da bu kavramların onlar için var olmadığını ifade eder. 
Toprağa bağımlı olmadıkları için gereksinim duydukları bir şey değildir yurt kavramı. Yine yaşam biçimleri göz önüne alındığında kendilerini zaman dâhil belli bir düzene uymakla görevli görmedikleri de neye ne kadar değer verdiklerini göstermesi açısından önemlidir.

Çingenecenin ilginç bir özelliği, iletişim kurmaktan çok duyguları anlatmak için kullanılan bir dil olmasıdır. Herhangi bir konuda genellikle herkes aynı düşünceyi paylaştığı için dilin temel işlevi fikir alışverişinden ziyade toplumsallaşmayı sağlamaktır (Fonseca, 2002: 71). Bir konuda genellikle aynı kanıda olmalarının getirmiş olabileceği bir özellikleri de soru cevap yerine karşılıklı çekilen kısa nutuklar biçiminde konuşmalarıdır (Yoors, 2005: 299). Bunun altında, sormanın cevap almak için doğru yol olmadığı düşüncesi de yatmaktadır (Fonseca, 2002: 24). Yalancı olduklarıyla ilgi bir önyargı geliştirmeden önce aslında meraklı gacoları yanlış bilgilendirmenin köklü bir Çingene geleneği olduğunu göz önüne almak gerekir (Fonseca, 2002: 66). Yani birbirlerine yalan söylemezler. Ayrıca gerçeğin ancak Çingenece anlatılabileceği inancına sahip oldukları için aynı soruya her seferinde farklı cevap vermekten de çekinmezler. Bunda bir tutarsızlık görmemelerinin nedeni ise Çingeneleri yabancı bir dille konuşmaya zorlayıp onların yalan söylemelerine neden olanların gacolar olduğunu düşünmeleridir (Yoors, 2005: 89).

Ağlayan Dağ ve Susan Nehir'de Çingenelerin birbirlerine değil ama gacolara çok yalan söylemelerinin bir nedeni de sadece eğlenmek olarak açıklanır. Daha doğrusu Çingeneler duyulmak istenileni söyler ve diğerlerine iyi vakit geçirtmek isterler. Bu konukseverlikten öte, bir sanat olarak değerlendirilir (Devecioğlu, 2015: 25).

Çingenelerin yalnız gacolardan değil, diğer Çingenelerden de sakladıkları belki tek şey çocuklarının gerçek adlarıdır. Çocuğun gerçek adı annesi tarafından kulağına fisıldanır. Anne bunu kocasına bile söylemek zorunda değildir çünkü ne kadar az kişi tarafından bilinirse o kadar iyidir. İnançlarına göre ad güç demektir. Belki de bu yüzden birinin gerçek adının bilinmesinin onu korumasız kılacağını düşünürler (Doughty, 2005: 38). Bahsedildiği gibi herkesin iki adı vardır: Dışarı ya da gaco adı ve ev adı (Mitchell, 1972: 21), (Devecioğlu, 2015: 177). Bunların dışında herkesin farklı soyadı taşıdığını da eklemek gerekir. Kendi içlerinde kim kimin kardeşidir bilirler ancak resmiyette her şey karışıktır. Bu yolla gacoların yazılı kayıtlarını altüst ederler. Ancak bu durumun Çingenelerin ensest olmakla suçlanmalarına da neden olduğu anlaşılmaktadır (Yoors, 2005: 162).

Dillerine verdikleri önemi Çingenelerin dışında hiç kimsenin Çingeneceyi öğrenemeyeceğini düşünmelerinde de görmek mümkündür. Onlarla birlikte geçirdiği sürede Çingeneceyi öğrenmek isteyen Fonseca'ya başarılı olamayacağı söylenir. Çünkü her sözcüğün bir eş anlamlısı vardır ve nerede ne zaman kullanılacağı ve ince ayrımlar onlara aittir. Bunları bilmek için Çingene olarak doğmak gerekir (Fonseca, 2002: 22).

\section{5. Kadın}

Çingene kadını ait olduğu toplum içinde her ne kadar ikinci planda gibi görünüyor olsa da özellikle marhime inancına dayanan kirletme güçleri nedeniyle aynı zamanda çekinilen bir 
varlık konumundadır. En korkutucu ve karanlık güçlerin kadınların elinde olduğunu belirten Fonseca, bu nedenle asıl hâkimiyetin de onlarda olduğunu ekler. Bahsedilen korkutucu güç, bir kadının bir erkeği sadece eteğini başına geçirme tehdidiyle ederek bile kirletebilecek olmasidir (Fonseca, 2002: 93).

İlginç olan nokta, kadının topluluk içindeki konumunun dönemsel olarak değişikliğe uğramasıdır. Örneğin doğum yapan kadın kirli olduğu için hem toplumdan ayrı tutulur hem de korku duyulan bir obje hâline gelir. Örneğin Karanlıkta Ateşler'de Anna'ya doğumdan sonraki iki hafta kimse yaklaşmayacaktır. Ayrıca yemek yapması ya da bir şey yıkaması da yasaktır. (Doughty, 2005: 38).

Ancak bu sorunlu sayılan iki hafta geçtikten sonra, çocuğu yokken yaşlı bir adamın önünde yürüyemeyen kadın, kucağında bebeği varken istediğini yapma hakkına kavuşur (Fonseca, 2002: 55). Anne olmanın dışında Çingene kadınını saygıdeğer bir konuma getiren durum ise yaşlılıktır. Yaşı kadına saygı duyulmasının nedeni ise onun kadınsı özelliklerini yitirip erkeğe daha çok benzemesiyle açıklanır. Kadınlar yaşlandıkları zaman erkeklerle beraber aynı sofrada oturabilirler hatta topluluk içinde konumları en sağlam olan bireyler konumuna gelirler (Fonseca, 2002: 93). Carmen'de de Çingenlere misafir olan kahraman, hasta ve yaşlı bir kadına ne kadar iyi bakıldığını, kendilerinin ise bir karış tahtalarda yattığını şaşırarak anlatır (Mérimée, 2011: 81).

Kadının erkeğe göre konumunu gösteren ilginç bir örnek de apartman düzeninde kendini gösterir. Çingene erkekleri kendi üst katlarında yaşayan kadınların marhimeye göre lekelenmeye yol açacağına inanırlar. Bu yüzden çok katlı apartmanlarda oturmayı reddetmişlerdir (Asseo, 2004: 123).

Çingene kadınlarıyla ilgili en yaygın önyargılardan biri onların teklifsiz bir hayat yaşadıklarıdır. Hem Batı hem de Doğu kaynaklı bazı eserlerde bu inanışı destekler biçimde kadınlar şehvetli ve ahlâksız olarak çizilmişlerdir. Kuşkusuz bunda yabancı olana egzotik bakışın ve erkek egemen yorumun da etkisi büyüktür. Yani aslında okurun istediği şey verilmiştir. Örneğin Çingenem'de aldatmak genel olarak Çingene toplumunda sık görülen bir şeymiş gibi sıklıkla işlenmiştir. Ayrıca eserdeki Çingenelerin bir ırmakta kadınlı erkekli çıplak şekilde yıkanmaları, kadının bedeninin geleneğe göre olan durumu belliyken pek de inandırıcı görünmemektedir (Stancu, 1971: 102).

Benzer şekilde bir kadının kayınpederi ile doğrudan göz teması kurmasının ayıp sayıldığı bir toplulukla (Fonseca, 2002: 57), Hayattan Sahifeler'deki gelin kayınpeder ilişkisinin -kadın kayınpederinin yanında belden aşağısı açık şekilde gezer (Gürpınar, 2015: 40) yaşandığı topluluk arasındaki fark çok büyüktür. Hâlbuki kadının belden yukarısının çıplak tasvir edilmesi daha mantıklıdır çünkü Çingeneler arasında göğüs bebekle ilgili görüldügüü için utanılacak bir şey değildir (Fonseca, 2002: 53). Benzer yaklaşım Stroheim’in eserinde de görülür. Bir eğlencede köylüler için çıplak dans eden Paprika’ya diğer genç erkek ve kızlar da katılır. Sürekli şehvetten, ihtirastan bahseden yazar, adeta cinsel içerikli bir ayini betimler ya da görülmek isteneni gösterir (Stroheim, 1954: 57).

Türlü önyargılara rağmen Çingene kadınlarının evlilik, bekâret ve sadakat konularında 
tutucu olduklarını gösteren örnekler azımsanmayacak kadar çoktur. Örneğin Çingene Kızı'nda genç bir kız bekâretinin en önemli hazinesi olduğunu söylerken (Cervantes, 2010: 53), Carmen'de kendisine bir avuç altın teklif eden adamı reddeden Çingene kadınından bahsedilir. Yine bir Çingene kadınının kendi soyundan olmayan bir erkeğe en küçük bir yakınlık duymasının görülmemiş şey olduğu da eklenir (Mérimée, 2011: 98). Aynı şekilde, kendilerine verdikleri adlardan birinin koca anlamına gelen "Rome" olduğu söylenir. Bu da evliliğe verdikleri değeri gösterir (Mérimée, 2011: 80).

Yine başka bir öyküde Çingene kızları ile ilgili abartılı hikâyelerin doğru olmadığını belirten New York'lu bir Çingene kralı, yıllardır içlerinde olduğu hâlde hayat kadınlığı yapan bir Çingene ile karşılaşmadığını aktarır (Mitchell, 1972: 25). Ona göre Çingene kadını her anlamda medenileşmiş kadından üstündür. Elastiki yürüyüşleri sayesinde güzel görünebilmek için korseye ihtiyaç duymazlar. Gaco kadınlarının çoğunun ise bir araba beygirinden daha çok koşum taşıdıklarını iddia eder (Mitchell, 1972: 29). Örneklerin bir kısmından anlaşılabileceği gibi önyargılı bakış açısı, Çingene kadınını ahlâksız gibi gösterme eğilimindedir. Bunda yaygın inanışı olduğu gibi kabul etmenin de etkisi vardır. Ancak birçok eserde, özelikle de otobiyografik olanlarda Çingene kadınlarının geleneklerine ve ailesine bağlı, sadık bir eş olarak çizildikleri de görülebilmektedir.

\section{6. Çocuk}

Çingenelerin çocuklarına verdikleri önem henüz doğumla başlayan ritüellerle kendisini gösterir. Örneğin yeni doğan bebeğin kundağı kem gözlerden korunması için muskalarla donatılır. Kırmızı sağlık ve mutluluğun rengi olarak görüldüğünden kırmızı bir ip koparılıp kundağın içine sıkıştırılır. Bu aynı zamanda Çingenelerin neden kırmız/pembe tonlarını bu kadar çok kullandıklarını göstermesi açısından açıklayıcıdır. Bebekler marhimenin tersini yanı saflığ́ temsil ettiği için çok sevilir (Fonseca, 2002: 56). Bebek üç günlük olunca annesi Üç Ruh için onu yere yatırıp çevresine halka hâlinde üç parça ekmek, üç kadeh şarap yerleştirir. (Doughty, 2005: 51). Pek çok kültürde olduğu gibi erkek çocuk Çingenelerde de önemlidir Aksi olana dek ise ilk çocuktan her zaman erkek olacakmış gibi söz edilir. (Doughty, 2005: 26).

Çingene topluluklarında dikkat çeken bir nokta da çocuklara karşı sergilenen kaba tutumdur. Ancak Fonseca, çocukların bundan rahatsız gibi görünmediklerini ekler. Çocuklarına böyle davranmalarının nedeni çocukların zor koşullara alışmalarını, hayata karşı güçlü bir duruşa sahip olmalarını sağlamaktır (Fonseca, 2002: 56).

Çocuk eğitimindeki başka bir yöntemse çocuğun bir yabancıyla dalga geçmesi için teşvik edilmesidir. Çocuk yediği tokatlara rağmen alaya devam ederek bu sınavdan geçer. Bu oyunla çocuklara korku veya fiziksel acı nedeniyle istediği bir şeyi yapmaktan kaçınmamayı öğretirler. Onlara göre insan ruhunu harap eden korku, kötünün sembolik niteliğidir. Böylelikle korkunun hayatlarında bir engel olarak var olmasına izin vermemiş olurlar (Yoors, 2005: 232).

Çocukların son derece cüretkâr ve saldırgan görünmeleri topluluğun mahremiyetini korumak, diğerlerini onlardan uzak tutmaktır. Kirli, pasaklı görüntüleriyle içinde yaşadıkları ortamın da farklı görünmesini sağlarlar. Yoors, dikkatle bakıldığında sağlıklı, neşeli, rol 
yeteneği yüksek çocukları fark etmenin mümkün olduğunu da ekler (Yoors, 2005: 87). Sonuç olarak korunup kollanırlar, hayatın zorluğuna alışmaları ve korkusuz olmaları için eğitilirler. Dışarıdan bakanın arsızlık olarak gördüğ̈̈ şey, aslında bir var olma mücadelesinde zorunlu bir tavır olarak geliştirilmiştir.

\section{Sonuç}

Gerek edebî eserlerden gerek araştırma kitaplarından gerekse otobiyografik romanlardan derlenen tüm konu başlklarına bakıldığında Çingenelerin hiçbir şeye inanmadıkları önyargısının hatalı olduğu açıkça görülmektedir. Yüzyıllar öncesinden dünyanın çok farklı coğrafyalarına dağılmış olan farklı Çingene toplulukları olağan bir asimilasyona uğramış olsalar da belli başlı geleneklerinden uzaklaşmamışlardır. Kadının toplum içindeki konumu, temizlikle ilgili inançlar, paraya verilen değer ya da onun kullanım şekli ve hayata bakış açısı noktalarındaki benzerlikler ilgi çekicidir. Dikkate değer diğer bir nokta da Türk ve Batı edebiyatının önemli eserlerinden ikinci sınıf romanlarına kadar Çingenelerle ilgili olumsuz görüşler üzerinde uzlaşılmış olunmasıdır. Bunun ana nedenlerinden biri tabii ki ötekileştirme kavramıyla açıklanabilir.

Çingenelerin öteki olarak görülmelerinin ilk nedeni doğal olarak ilk başlarda konargöçer bir yaşantı sürmeleridir. Daha önce de belirtildiği gibi yerleşik olmayan toplulukların çoğu öyle olmasalar bile Çingene olarak görülmüşlerdir. Şehirde bir konut sisteminde yaşayan insan için konargöçerlik ne kadar anlaşılmazsa, konargöçer bir Çingene için de dört duvar arasında yaşamak anlaşılmazdır. Ancak bir topluluğun ötekileştirilmesi için azınlık olması yeterlidir. Şehir hayatı, yani belli bir sistem içerisinde, belli yasalara göre yaşamak, yine çoğunluk tarafindan medeniliğin de sembolü olarak görülür. Şu hâlde Çingeneler vahşi olarak tanımlanırlar. Birçok eserde "ehlileştirilmeye" çalışılmaları da bu nedenledir. Faydacıılık, rasyonalizm, pozitif bilimlerle yeniden biçimlenen dünyada, üzerinde anlaşılan medeniyet kavramının içinde Çingenelerin oldukları gibi kabul edilmeleri mümkün değildir.

İktidar için de belli bir yerde sabit olmayan toplulukları bürokrasiye dâhil etmenin zorluğu açıktır. Hem mülk kavramına sahip olmadıkları hem de bir adresleri olmadığı için izlenmeleri zordur. Yani bir anlamda yukarıda bahsedilen "ehlileştirme" kavramı ile aynı zamanda Çingeneleri kontrol altına alma amacı güdülmüş̧ür. $\mathrm{Bu}$, devlet mekanizmasının durduğu yerden bakıldığında anlaşılır bir tutumdur. Açıklanması daha zor olan nokta ise Çingenelerin kontrol altına alındıkları zaman da hemen her konuda ayrımcılığa uğramalarıdır.

Çingeneler inançsız değillerdir ancak herkes gibi bir dini değerler sistemine de sahip olmadıkları açıktır. Dinsiz kabul edilmelerinin nedenlerinden biri, korkulacak bir Tanrı kavramına uzak olmalarından kaynaklanmaktadır. Aynı şekilde hiçbir eserde ceza çekilecek bir cehennemden bahsedilmemesi de benzer etkiyi yaratmıştır. Öteki etken de günün belli saatlerine ya da haftanın belli günlerine ayrılmış sistemli bir dini ritüellerinin yokluğundan kaynaklanır. Tüm bunlar onların dinsiz sayılmaları için yeterlidir. Aynı şekilde yemek yeme, uyuma, çalışma gibi günlük rutinlerin de medeni yaşam tarzına aykırı olması uyumsuz sayılmaları için geçerli sebeplerdir. 
Tüm bunların üzerinde olan soru ise dışlanmalarının da ötesinde maruz kaldıkları şiddetin neden olağan görüldüğüdür. Bu noktada çoğu Çingenelerle ilgili olmayan ama toplumun zayıf olarak gördüğüne bakış açısını yansıtması bakımından birkaç atasözü yol gösteri olacaktır: İt ürür kervan yürür/ Köpekler istedi diye atlar ölmez/ Kurt kocayınca itlere maskara olurmuş/ Aslan yattığı yerden belli olur/ Eşeğe altın semer de taksalar yine eşektir/ Çingeneye saray vermişler, bahçesinde çadır kurup oturmuş/ Sen bir garip çingenesin, telli zurna nene gerek.

Köpek, eşek, kurt, kısmen at ve aslan ile ilgili atasözleri, Çingenelerin eziyet çekmelerinin neden olağan görüldüğüyle ya da umursanmadığıyla ilişkilidir aslında. Şöyle ki, köpek ve eşeğe bakış olumsuzdur ve bu düşünce üzerinde anlaşılmış gibidir. Bunun en belirgin nedeni hayvanlar arasında da düşük seviyede görülüyor olmalarıdır. Her ikisi de insanlara muhtaçtır ve atasözlerinin nitelediği anlamda değersizdirler. Kurt, at ve aslan ise daha çok asil olarak adlandırılan hayvanlardır. Kurdun ve aslanın hem insana ihtiyacı yoktur hem de güçlüdürler. Eşeğin atın karşısında zaten hiç şansı olmamıştır. Çünkü eşek sadece yük taşımak ve çok çalışmakla ilişkilendirilmiştir. Bilinçli şekilde inat ettiği düşünüldüğü için (yorulduğu düşünülmez) eziyet edilmesinde sakınca görülmez. Bir metafor olarak eşeklik (Şenel, 2019) ona doğuştan verilmiştir ve değiştirilemez.

Çingenelerin ya da ötekileştirilen her topluluğun durumu benzer şekildedir. Çingenelerin pis, yabani olmakla suçlandıkları için eziyet görmelerinde de bir sorun bulunduğu düşünülmez. $\mathrm{Bu}$ yüzden olaylara bir de onların gözünden bakmak söz konusu olamayacağından bir Çingenenin ne yaşadığı ve ne düşündüğü de önemsiz görülür.

Gerek Türk gerekse Batı edebiyatında yer alan Çingene tipine bakıldığında - ki nitelikli olsun ya da olmasın birçok eserde tip olarak çizilmişlerdir - benzer özellikler çerçevesinde ele alındıkları görülür. Batı edebiyatında daha çekici olmak adına egzotik bir imajla gösterilen Çingeneler Türk edebiyatında daha yerel düzeyde ele alınmıştır. Ancak yüzeysel değerlendirmeler bakımından önemli bir fark yoktur. Müziğe ve sanata olan yatkınlıkları ile bulundukları ortamı şenlendirmeleri sınırlı sayıdaki olumlu yönleri olarak takdir edilmiştir.

İlginç olan durum Çingene toplulukları arasında da kast sisteminden gelen sınıf ayrımının var olmasıdır. Türkiye'de müzisyenlerin büyük olasılıkla diğerlerinden daha fazla kazanca sahip oldukları için üst seviyede görülmeleri de bundandır. Tabii bir demirci ustasının mesleğini üstün görmesi nedeniyle aynı payeyi kendine verdiği ya da bir konargöçerin, müzisyen de olsa bir yerleşiği küçük gördüğü anlaşılmaktadır.

Çingenelik kavramının çıkmaz noktalarından biri ise Çingenelerle ilgili olumsuz görüşlerin sıralanmasının ya da bilinmeyen örneklerin verilmesinin var olan imaja olumlu bir katkı yapamayacağıdır. Çingeneler "öyle" değildir denilirken bile nasıl olmadıklarını ifade etme zorunluluğu aynı imaja gönderme yapmaktadır. Çektikleri eziyeti eşek ve köpek mecazlarıyla açıklamaya çalışırken de aynı kısır döngüye girilmiş olunur. Hatta "Çingene" ya da daha yumuşatılmış olan "Roman" tabirini kullanmak bile kendi içerisinde bir hakareti temsil ettiği için aynı çıkmaza girilir. Diğer sorunlu durum ise geçmişle ilişkileri yazılı kaynaklara dayanmayan ve yeterli eğitim alma imkânına sahip olmayan Çingenelerin çoğunluğunun ne bu tartışmalardan haberdar olmalarının ne de bu çalışmayı okumalarının mümkün olmamasıdır. 
Yine de son cümle olarak inançsız, amaçsız, anlamsız bir hayat sürdüğü düşünülen Çingenelerin aynı konularda "gaco"ları da benzer şekilde yargıladıklarıdır. Yani onlara göre de Çingene olmayanlar, değer verdikleri şeyler noktasında gülünç, eksik ve anlaşılmazlardır. $\mathrm{Bu}$ bir kısırdöngüdür ve muhtemelen tüm Çingeneler medeni hayatın zorlamasıyla geleneklerini kaybedip çoğunluğa katılana kadar da böyle devam edecektir.

Hiç kuşkusuz Çingenelerle ilgili yapılacak araştırmalar çeşitlendirilmeye muhtaçtır. Çocuk edebiyatı açısından bakıldığında Çingeneleri ele alan çocuk kitapları ve masallar farklı inceleme konuları olarak ortaya çıkar. Yine folklorik açıdan hem Çingenelere ait atasözleri ve deyimleri hem de onlar hakkında türetilmiş olanları başka bir çalışmanın konusudur. Farklı disiplinlere aynı anda hitap eden Çingenelik kavramı zengin bir kaynak olarak nitelikli araştırmalara olanak sağlayacaktır.

\section{Notlar}

1 Türk edebiyatında Çingenelerle ilgili ayrıntılı bilgi için bkz. Oymak, A. (2019) Gypsies in Turkish Literature. Turkish Studies, 14, 1417-1435. DOI: 10.29228/TurkishStudies.23463. Bu makalede de belirtildiği gibi Çingene kavramı tüm ayrıştırıcı nitelemelerin dışında evrensel özelliği ile kullanılmıştır. Referans olarak da Çingene kökenli araştırmacıların, Roman gibi farklı adlar kullanmanın faydasızlığı ve Çingene adının temizlenmesi gerektiği düşüncesi alınmıştır.

2 Şenel, Ö. Ortadoğu'da eşek metaforu. Erişim tarihi 12. 08. 2019, https://omerwsenel.blogspot. com/2014/01/ortadoguda-esek-metaforu.html.

\section{Kaynakça}

Aksel, M. (2004). Çingene şalvarı (H. Aydın, Haz.) Çingene öyküleri içinde (13-18), İstanbul: İnk1lap.

Alpman, N. (2014). Çingeneler başka dünyanın insanları. İstanbul: Ozan.

Asseo, H. (2004). Çingeneler bir Avrupa yazgısı. İstanbul: Yap1 Kredi.

Berger, H. (2015). Çingene mitolojisi. Ankara: Bilgesu.

Cervantes, M. D. (2010). Çingene kızı. İstanbul: Özgür.

Coelho, P. (2008). Portobello cadist. İstanbul: Can.

Çelebi, E. (2011). Seyahatname (8). İstanbul: Yap1 Kredi.

Devecioğlu, A. (2015). A ğlayan dă̆ susan nehir. İstanbul: Metis.

Dinçer, H. (2014). Bir çingenenin romant. İstanbul: Ozan.

Doughty, L. (2005). Karanlıkta ateşler. İstanbul: İş Bankası.

Erdoğdu, S. (2016). Romanika. İstanbul: Pamiray.

Fonseca, I. (2002). Beni ayakta gömün. İstanbul: Ayrıntı.

Fraser, A. (2005). Avrupa halkları çingeneler. İstanbul: Homer.

Gorki, M. (2004). Makar çudra (H. Aydın, Haz.) Çingene öyküleri içinde (205-224), İstanbul: İnk1lap. 
Gürpınar, H. R. (2015). Hayattan sahifeler. İstanbul: Papersense.

Hugo, V. (1988). Notre dame'in kamburu. Ankara: Bilgi.

Kaygıl1, O. C. (1972). Çingeneler. Ankara: Bilgi.

Kılıç, H. (1986). Çingenem çengi çengi. Ankara: Saypa.

Kivi, A. (1975). Yedi kardeşler. Ankara: Devlet Kitapları.

Martinez, N. (1992). Çingeneler. İstanbul: İletişim.

Mather, A. (1982). Çingene düğünü. İstanbul: Gelişim.

McCann, C. (2007). Zoli bir aykırı çingene. İstanbul: Merkez Kitaplar.

Mérimée, P. (2011). Carmen. İzmir: İlya.

Midhat, A. (2001). Letaif-i Rivayat. İstanbul: Çağr1.

Mitchell, J. (1972). Çingene kralı (T. Alangu, Haz.) Dünyadan ve bizden çingene hikâyeleri içinde (29-40), İstanbul: Nil.

Muradi, P. (2007). Romanika çingeneler. İstanbul: Pentagram.

Önder, N. (1975). Çingeneler ve bir travay. Folklora Doğru, 41, 22-26.

Podgoreç, V. (1978). Çingeneler arasında. İstanbul: Ya/Ba.

Puşkin, A. (1990). Çingeneler. Ankara: Damar.

Putnam, V. (1972). Furi-dai nasıl öldü? (T. Alangu, Haz.) Dünyadan ve bizden çingene hikâyeleri içinde (70-77), İstanbul: Nil.

Stancu, Z. (1971). Çingenem. Ankara: Bilgi.

Stroheim, E. V. (1954). Çingene aşkı. İstanbul: Ekicigil.

Tokmakçığlu, E. (1975). Çingene pilici. İstanbul: Habora.

Yoors, J. (2005). Çingeneler opre roma. İstanbul: Çiviyazıları.

\section{Elektronik kaynaklar}

Arnold, M. Scholar gypsy. Erişim tarihi 21. 07. 2019,

https://www.poetryfoundation.org/poems/43606/the-scholar-gipsy.

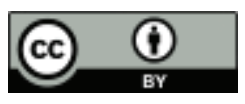

Bu eser Creative Commons Atıf 4.0 Uluslararası Lisansı ile lisanslanmıştır. (This work is licensed under a Creative Commons Attribution 4.0 International License). 